\title{
Molecular and Crystal Structures of $\mathrm{Cp} * \mathrm{M}\left(\mathrm{S}_{2} \mathrm{~N}_{2}\right)(\mathrm{M}=\mathrm{Co}, \mathrm{Rh}, \mathrm{Ir})$ and related compounds
}

\author{
Vit Matuska, ${ }^{[a]}$ Karla Tersago, ${ }^{[b]}$ Petr Kilian, ${ }^{[a]}$ Christian Van Alsenoy, ${ }^{[b]}$ \\ Frank Blockhuys, ${ }^{[b]}$ Alexandra M. Z. Slawin ${ }^{[a]}$ and J. Derek Woollins ${ }^{*}[a]$
}

\begin{abstract}
$\mathrm{Cp} * \mathrm{Rh}\left(\mathrm{S}_{2} \mathrm{~N}_{2}\right)$ was prepared as a microcrystalline solid using $\left[\mathrm{S}_{4} \mathrm{~N}_{3}\right] \mathrm{Cl}$ in liquid ammonia or $\left[n \mathrm{Bu}_{2} \mathrm{Sn}\left(\mathrm{S}_{2} \mathrm{~N}_{2}\right)\right]_{2}$. It was characterised by $\mathrm{NMR}$, IR and Raman spectroscopy and mass spectrometry. Low-temperature crystal structures of $\mathrm{Cp} * \operatorname{Co}\left(\mathrm{S}_{2} \mathrm{~N}_{2}\right)$ and $\mathrm{Cp} * \operatorname{Ir}\left(\mathrm{S}_{2} \mathrm{~N}_{2}\right)$ were determined. The experimental characterisation of the $\mathrm{Cp} * \mathrm{M}\left(\mathrm{S}_{2} \mathrm{~N}_{2}\right)$ complexes is complemented by calculated geometries and bond orders at the DFT/B1B95 level of theory.
\end{abstract}

Keywords: 5,1,3,2,4-Metalladithiadiazoles / Rhodium / Molecular structure / Density Functional Theory / X-Ray Diffraction / Bonding / Spectroscopy.

[a] University of St Andrews, School of Chemistry, North Haugh, St Andrews, Fife, KY16 9ST, United Kingdom Fax:

E-mail:

[b] University of Antwerp, Department of Chemistry, Universiteitsplein 1, B-2610 Wilrijk, Belgium 


\section{Introduction}

As a consequence of the fascinating discovery of the conductive properties of $(\mathrm{SN})_{\mathrm{x}}$ polymer, sulfurnitrogen chemistry has registered a rapid development in all its areas since 1973. ${ }^{[1]}$ As a part of that, inorganic sulfur-nitrogen rings became so popular that even after three decades of research the interest in them continues. The five-membered rings (dithiadiazoles) have attracted special attention mostly because of their ability to form radicals. ${ }^{[2]}$ While dithiadiazoles have been investigated in detail, ${ }^{[2]}$ metalladithiadiazoles have not received attention with similar intensity. Moreover, only a small number of reports have been published on 5,1,3,2,4-metalladithiadiazoles with a half-sandwich structure stabilised with cyclopentadienyl $(\mathrm{Cp})$ or pentamethylcyclopentadienyl $\left(\mathrm{Cp}^{*}\right)$ ligands. ${ }^{[3-6]}$ There were several attempts to synthesise both $\mathrm{Cp}$ and $\mathrm{Cp}{ }^{*}$ metalladithiadiazoles using various transition metals. ${ }^{[5]}$ Unfortunately, despite quite a wide range of commercially available possible starting materials, only 5,1,3,2,4-metalladithiadiazoles containing Group 9 metals could be prepared with partial success. $\operatorname{CpCo}\left(\mathrm{S}_{2} \mathrm{~N}_{2}\right)$ (1) was investigated in detail, whereas the X-ray structure of $\mathrm{Cp}^{*} \operatorname{Co}\left(\mathrm{S}_{2} \mathrm{~N}_{2}\right)$ (2) has not

been reported. ${ }^{[3-5]} \mathrm{CpRh}\left(\mathrm{S}_{2} \mathrm{~N}_{2}\right)(3), \mathrm{Cp} * \mathrm{Rh}\left(\mathrm{S}_{2} \mathrm{~N}_{2}\right)(4)$ and $\mathrm{Cp} \operatorname{Ir}\left(\mathrm{S}_{2} \mathrm{~N}_{2}\right)$ (5) have not yet been synthesised and $\mathrm{Cp} * \operatorname{Ir}\left(\mathrm{S}_{2} \mathrm{~N}_{2}\right)(\mathbf{6})$ thus remains the only prepared and fully characterised iridium analogue (Figure $1) .^{[6]}$
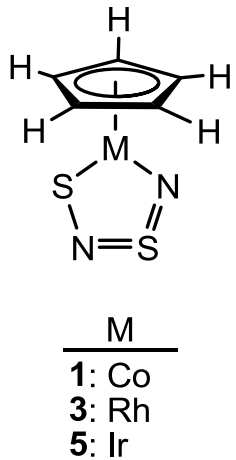

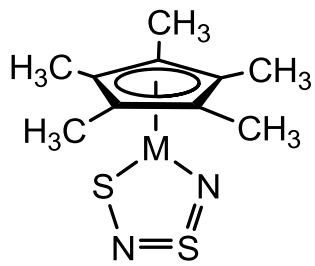

$\frac{M}{\text { 2: Co }}$
4: Rh
6: Ir

Figure 1. Structural formulae and numbering of the title compounds. Formal bonding is displayed.

Quantum chemical studies on metalladithiadiazoles continue to represent a challenge as the complexity of the calculations increases dramatically with the growing number of atoms/electrons involved and with the presence of heavier elements such as phosphorus, sulfur and transition metals. Thanks to the development of new approaches within density functional theory (DFT) in the early 2000s, it has become possible to study more advanced systems containing heavier elements. ${ }^{[7-10]}$ Since then, we focused our attention on sulfur-nitrogen ring compounds and we found suitable DFT methodologies which led to successful descriptions of Roesky's sulfoxide $\left(\mathrm{S}_{3} \mathrm{~N}_{2} \mathrm{O}\right){ }^{[11]}$ Roesky's ketone $\left(\left(\mathrm{S}_{2} \mathrm{~N}_{2}\right) \mathrm{CO}\right)^{[12]}$ and other ring compounds bearing the $-\mathrm{SNSN}-$ fragment. ${ }^{[13]}$ Experience from previous work combined 
with the advantage of the use of hybrid functionals enabled us to perform a detailed study on $\mathbf{1}$ with the emphasis on the geometry of the molecule, its bonding, aromaticity, and reactivity. ${ }^{[14]}$

In this article we report the preparation and characterisation of the missing 5-( $\eta^{5}$-pentamethylcyclopentadienyl)-5,1,3,2,4-rhodiadithiadiazole (4) alongside the low-temperature crystal structure of $\mathbf{2}$. The molecular structures of compounds $\mathbf{2 , 4}$ and $\mathbf{6}$, together with those of their non-pentamethylated counterparts, are discussed in terms of calculated (DFT/B1B95) gas-phase geometries and bond orders, and are compared to the structures found in the solid state.

\section{Results and discussion}

\subsection{Syntheses of the complexes}

The complex 2 was prepared according to published procedure from $\mathrm{S}_{4} \mathrm{~N}_{4}$ and $\mathrm{Cp} * \mathrm{Co}(\mathrm{CO})_{2}(\mathrm{Scheme}$ $1)^{[4]}$

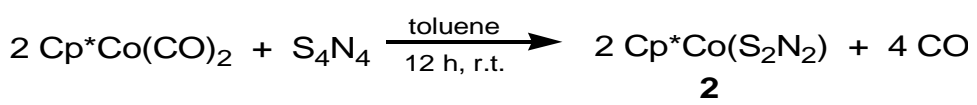

Scheme 1

The mechanism of the reaction is not completely understood but it was proposed that in the initial step $\mathrm{S}_{4} \mathrm{~N}_{4}$ is coordinated to the metal centre, which promotes cleavage of $\mathrm{S}_{4} \mathrm{~N}_{4}$ into $\mathrm{S}_{2} \mathrm{~N}_{2}$. The next step is oxidative addition of $\mathrm{S}_{2} \mathrm{~N}_{2}$ to the metal. ${ }^{[15]}$ In contrast to $\mathrm{Co}^{(\mathrm{I})}$ centre, the oxidative addition of $\mathrm{S}_{2} \mathrm{~N}_{2}$ to a $\mathrm{Rh}^{(\mathrm{I})}$ or $\mathrm{Ir}^{(\mathrm{I})}$ centre leads to formation of insoluble precipitates which are thought to be of polymeric nature. ${ }^{[5]}$ The method proved unsuitable also for the synthesis of numerous other metalladithiadiazoles. ${ }^{[5]}$ We found that 4 can be prepared in two synthetic routes but its instability makes its purification and isolation difficult.

The reaction of $\left[\mathrm{S}_{4} \mathrm{~N}_{3}\right] \mathrm{Cl}$ with liquid ammonia is a safe and clean procedure, which has been used previously for the preparation of a variety of five-membered metal-sulfur-nitrogen rings. ${ }^{[16]}$ The mechanism of this reaction and its stoichiometry are complex and are not completely understood to date. The $\left[\mathrm{S}_{4} \mathrm{~N}_{3}\right] \mathrm{Cl} / \mathrm{NH}_{3}$ (l) system reacted with $\left[\mathrm{Cp} * \mathrm{RhCl}_{2}\right]_{2}$ (Scheme 2) to give a beige/brown mixture of solids, which produced a complex ${ }^{1} \mathrm{H}$ NMR spectrum with two dominant singlets at 1.80 and $2.07 \mathrm{ppm}$.

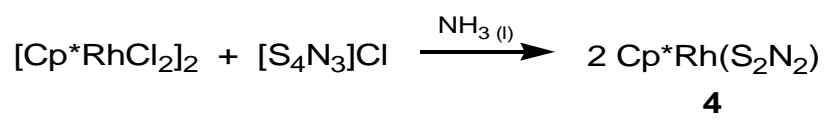

Scheme 2 
The ${ }^{13} \mathrm{C}$ NMR spectrum of the crude mixture contained signals at 9.26 and 94.94 ppm accompanied by a weak singlet at $8.70 \mathrm{ppm}$. The assignment of the signals was based on an ES ${ }^{+} \mathrm{TOF}$ mass spectrum, which showed two peaks corresponding to $\left[\mathrm{Cp} * \mathrm{Rh}\left(\mathrm{S}_{2} \mathrm{~N}_{2} \mathrm{H}\right)\right]^{+}$(330.95) and decamethylrhodiocenium cation $\left[\mathrm{Cp}^{*} \mathrm{RhCp}^{*}\right]^{+}$(373.11). Given the composition of the liquid ammonia reaction system, the most probable decamethylrhodiocenium byproduct is $\left[\mathrm{Cp}^{*} \mathrm{RhCp} \mathrm{C}^{*} \mathrm{Cl}(\mathbf{7})\right.$. A comparison of the recorded ${ }^{1} \mathrm{H}$ and ${ }^{13} \mathrm{C}$ NMR spectra of the crude mixture of solids and those of 7 confirmed that the singlet at 1.80 ppm $\left({ }^{1} \mathrm{H}\right)$ and the one at $8.70 \mathrm{ppm}\left({ }^{13} \mathrm{C}\right)$ can be assigned to 7 , and thus the signal at $2.07 \mathrm{ppm}\left({ }^{1} \mathrm{H}\right)$ and those at 9.26 and $94.94 \mathrm{ppm}\left({ }^{13} \mathrm{C}\right)$ must belong to 4 . We determined the structure of $\left[\mathrm{Cp}^{*} \mathrm{RhCp} * \mathrm{Cl}(\mathbf{7})\right.$ and confirmed our assignment of the observed NMR spectrum for this species. ${ }^{[17]}$

An alternative strategy for the synthesis of $\mathbf{4}$ is the transmetallation reaction between $\left[n \mathrm{Bu}_{2} \mathrm{Sn}\left(\mathrm{S}_{2} \mathrm{~N}_{2}\right)\right]_{2}$ and $\left[\mathrm{Cp}^{*} \mathrm{RhCl}_{2}\right]_{2}$, in a fashion similar to the preparation of 6 (Scheme 3$) .{ }^{[6]}$

Scheme 3

$$
\begin{aligned}
& {\left[\mathrm{Cp}^{*} \mathrm{MCl}_{2}\right]_{2}+\left[n \mathrm{Bu}_{2} \mathrm{Sn}\left(\mathrm{S}_{2} \mathrm{~N}_{2}\right)\right]_{2} \frac{\mathrm{CH}_{2} \mathrm{Cl}_{2}}{8 \text { h, r.t. }} 2 \mathrm{Cp}^{*} \mathrm{M}\left(\mathrm{S}_{2} \mathrm{~N}_{2}\right)+2 n \mathrm{Bu}_{2} \mathrm{SnCl}_{2}} \\
& (\mathrm{M}=\mathrm{Rh}, \mathrm{Ir})
\end{aligned}
$$

TLC analysis of the crude mixture suggested decomposition of $\mathbf{4}$ on both silica and alumina. However, small amounts of pure 4 were obtained by a careful elution with an acetone/toluene (1:2) mixture from a silica column. Both the ${ }^{1} \mathrm{H}$ and ${ }^{13} \mathrm{C}$ NMR spectra were identical to the spectra of 4 prepared by the liquid ammonia route. The ES ${ }^{+}$TOF mass spectrum of pure 4 showed a single peak at $\mathrm{m} / z$ 330.99 $\left([\mathrm{MH}]^{+}\right)$. To obtain better yields, we attempted separations on silica, alumina, Bio-Beads together with dry and degassed solvents. Although the yields were very small, we were able to isolate $\mathbf{4}$ on every occasion, which demonstrates the reproducibility of the preparation method.

The complex 6 was prepared by a ligand exchange between $\left[\mathrm{Cp}^{*} \mathrm{IrCl}_{2}\right]_{2}$ and the tin reagent $\left[n \mathrm{Bu}_{2} \mathrm{Sn}\left(\mathrm{S}_{2} \mathrm{~N}_{2}\right)\right]_{2} .{ }^{[6]}$ It is noteworthy that for a successful synthesis of $\mathbf{6}$ the reactants must be mixed in solutions. The published addition of solid tin reagent in one portion to a solution of $\left[\mathrm{Cp}^{*} \mathrm{IrCl}_{2}\right]_{2}$ leads to the formation of a temporarily heterogeneous mixture, in which $\left[\mathrm{Cp}^{*} \mathrm{IrCl}_{2}\right]_{2}$ readily reacts with the gradually dissolving tin reagent to give complex $\mathbf{8}$ (Scheme 4). 


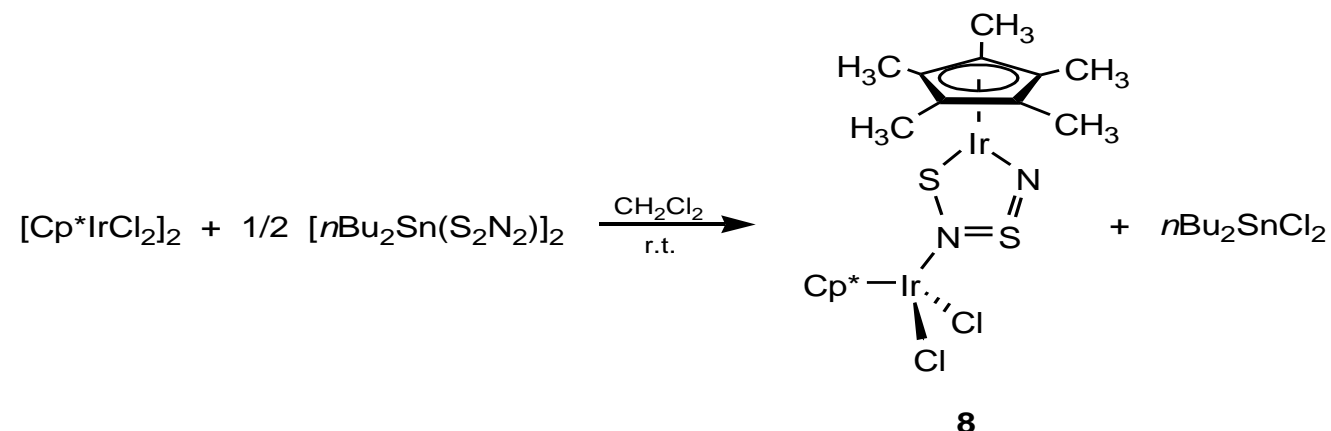

Scheme 4

\subsection{Molecular and crystal structures}

Suitable crystals of $\mathbf{2}$ were obtained as purple plates by recrystallisation from a hot hexane solution. Xray analysis confirmed the structure of $\mathbf{2}$ as 5 - $\left(\eta^{5}\right.$-pentamethylcyclopentadienyl)-5,1,3,2,4cobaltadithiadiazole. The $\operatorname{Co}\left(\mathrm{S}_{2} \mathrm{~N}_{2}\right)$ ring is planar and is perpendicular to the $\mathrm{Cp} *$ plane (Figure 2).
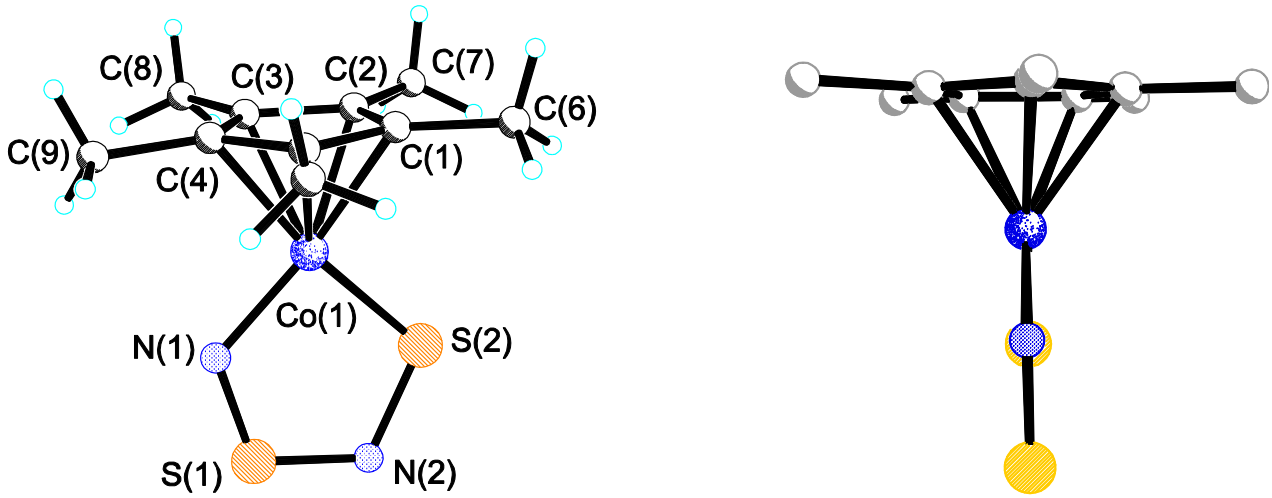

Figure 2. The crystal structure of 2

The low-temperature X-ray structure of $\mathbf{6}$ is nearly identical to the structure measured at 293 $\mathrm{K} .{ }^{[6]}$ In the low-temperature structure, the $\mathrm{Ir}-\mathrm{S}$ and all $\mathrm{N}-\mathrm{S}$ bond lengths appear slightly elongated, though the effect is modest. $\mathbf{2}$ and $\mathbf{6}$ show very similar crystal packing with stacking of molecules illustrated in Figure 3. Intermolecular contacts between two NSN sulfur atoms were observed in the packing of 6 (Figure 3), with the distance (3.612 $\AA$ ) being just on the edge of the sum of van der Waals radii $(3.60 \AA) .{ }^{[20]}$ 


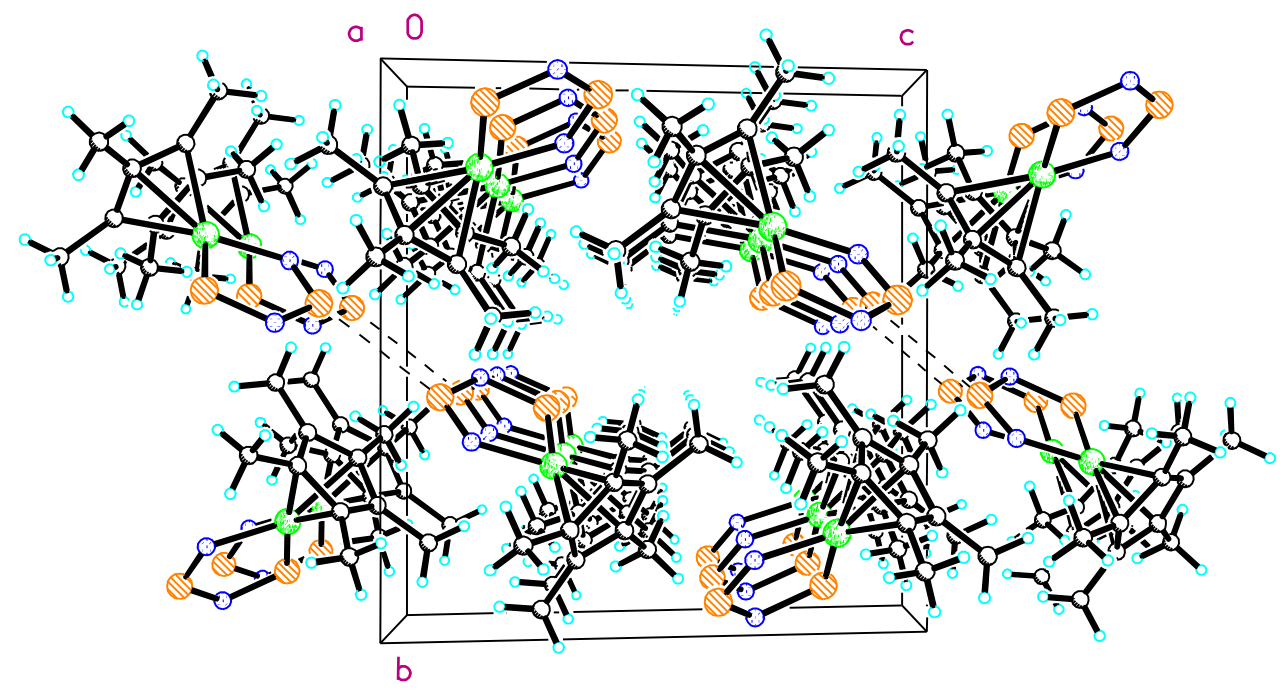

Figure 3. The crystal packing of $\mathbf{6}$ with highlighted intermolecular contacts

The low-temperature single-crystal X-ray structure of $\mathbf{8}$ revealed cocrystallisation of one molecule of $n \mathrm{Bu}_{2} \mathrm{SnCl}_{2}$ and a disordered molecule of toluene (Figure 4). The molecule of $\mathbf{8}$ consists of the $\mathrm{Cp} * \operatorname{Ir}\left(\mathrm{S}_{2} \mathrm{~N}_{2}\right)$ central unit, to which the $\mathrm{Cp}^{*} \mathrm{IrCl}_{2}$ ligand is bound.

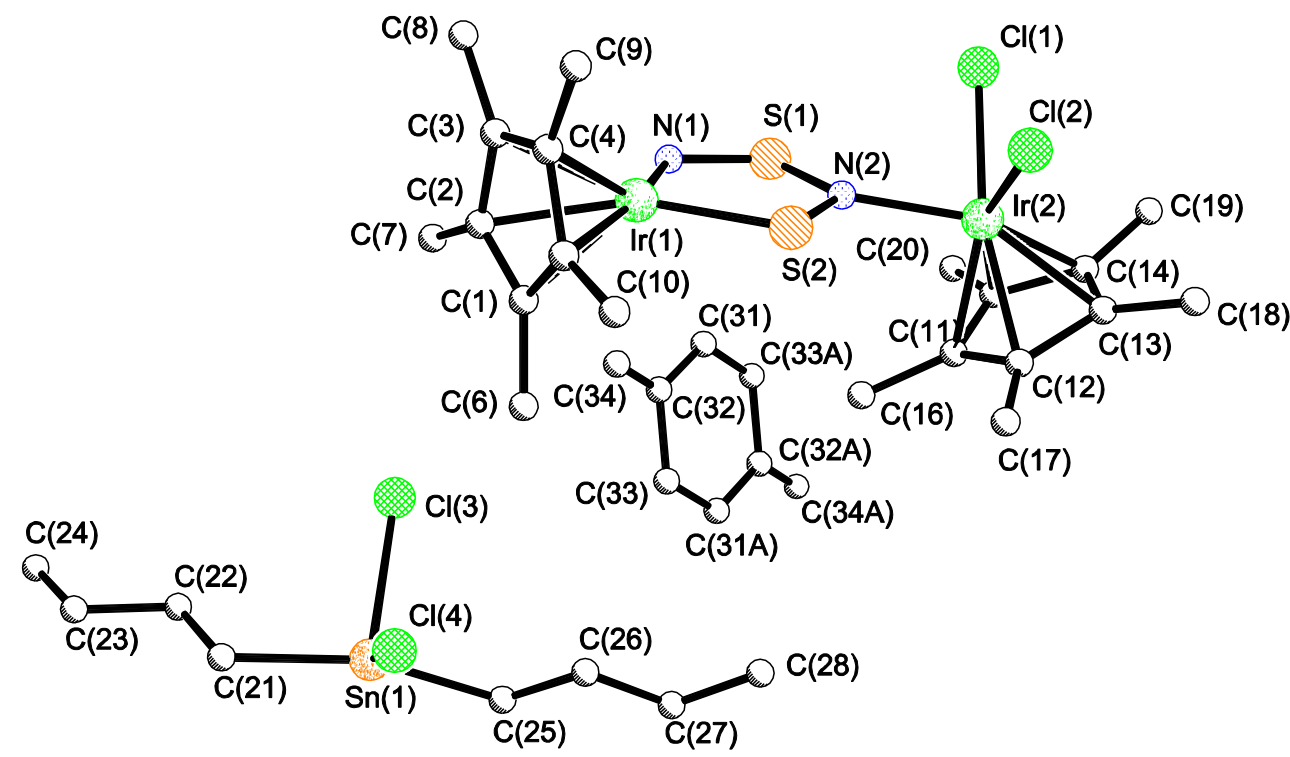

Figure 4. The X-ray structure of $\mathbf{8} \cdot n \mathrm{Bu}_{2} \mathrm{SnCl}_{2}$. Hydrogen atoms are omitted for clarity.

The influence of the $C \mathrm{p}^{*} \mathrm{IrCl}_{2}$ ligand on the $\mathrm{Cp} * \operatorname{Ir}\left(\mathrm{S}_{2} \mathrm{~N}_{2}\right)$ moiety can be described by a comparison between $\mathbf{6}$ and $\mathbf{8}$. The surroundings of the $\operatorname{Ir}(1)$ centre in 8 are virtually unaffected while the geometry of the $\left(\mathrm{S}_{2} \mathrm{~N}_{2}\right)$ unit changes considerably. In $\mathbf{8}$, the angles at both nitrogen atoms become wider and those at both sulfur atoms become more acute. Particularly noteworthy is the angle at the donor nitrogen atom $\mathrm{N}(2)$ which opens by nearly $2^{\circ}$, and the angle at $\mathrm{S}(1)$ which closes by approximately $2.4^{\circ}$. 
The reduction in the angle at $S(1)$ is especially striking taking into account that the $S(1)$ atom is formally bound by two double bonds in the $\operatorname{Ir}\left(\mathrm{S}_{2} \mathrm{~N}_{2}\right)$ ring. The bond lengths of the $C \mathrm{p}^{*} \operatorname{Ir}\left(\mathrm{S}_{2} \mathrm{~N}_{2}\right)$ moiety in $\mathbf{8}$ do not change as considerably as the angles. It is interesting to note that the $C \mathrm{p}^{*}-\operatorname{Ir}(2)$ distance is $0.054 \AA$ shorter than the $\mathrm{C} \mathrm{p}^{*}-\operatorname{Ir}(1)$ distance. This can be explained by the presence of the two chlorine atoms on $\operatorname{Ir}(2)$, which are withdrawing electron density from the metal centre forcing the $\mathrm{Cp}^{*}$ ring to be situated closer to $\operatorname{Ir}(2)$.

Attempts to obtain crystals of $\mathbf{4}$ were unsuccessful. Recrystallisation by gas-phase diffusion of hexane into a dichloromethane solution of $\mathbf{4}$ resulted only in deposition of a thin red film on the walls of a sample vial suggesting a low tendency of $\mathbf{4}$ to crystallise. Attempts to recrystallise $\mathbf{4}$ from a hot dichloromethane or toluene solution led to the formation of black tarry globules as a result of heat decomposition, while saturated toluene or dichloromethane solutions of 4 stored at $-20{ }^{\circ} \mathrm{C}$ over several weeks resulted only in separation of powdery precipitates. Powder diffractograms of several samples of 4 contained broad and badly defined peaks rising only slightly from a noisy baseline suggesting a microcrystalline substance with a very small particle size. When recrystallised from non-predried solvents $\left(\mathrm{CH}_{2} \mathrm{Cl}_{2} /\right.$ hexane), 4 hydrolysed into compound $\mathbf{9}$, which formed rosettes of fragile red needles at the bottom of the sample vial. The quality of the crystals was below average even after several recrystallisations but the X-ray structure could be solved. 9 consists of two $\mathrm{Cp} * \mathrm{Rh}$ units bridged by a $\left[\mathrm{S}_{3} \mathrm{~N}_{2}\right]^{2-}$ ligand and by the terminal sulfur of a thiosulfate anion (Figure 5). ${ }^{[21]}$ Metal complexes bearing either $\left[\mathrm{S}_{3} \mathrm{~N}_{2}\right]^{2-}$ or thiosulfate anion in a bridging position are known but no rhodium analogues have been reported. ${ }^{[22,23]} 9$ also contains both of these ligands in one molecule, which has not been observed before. 


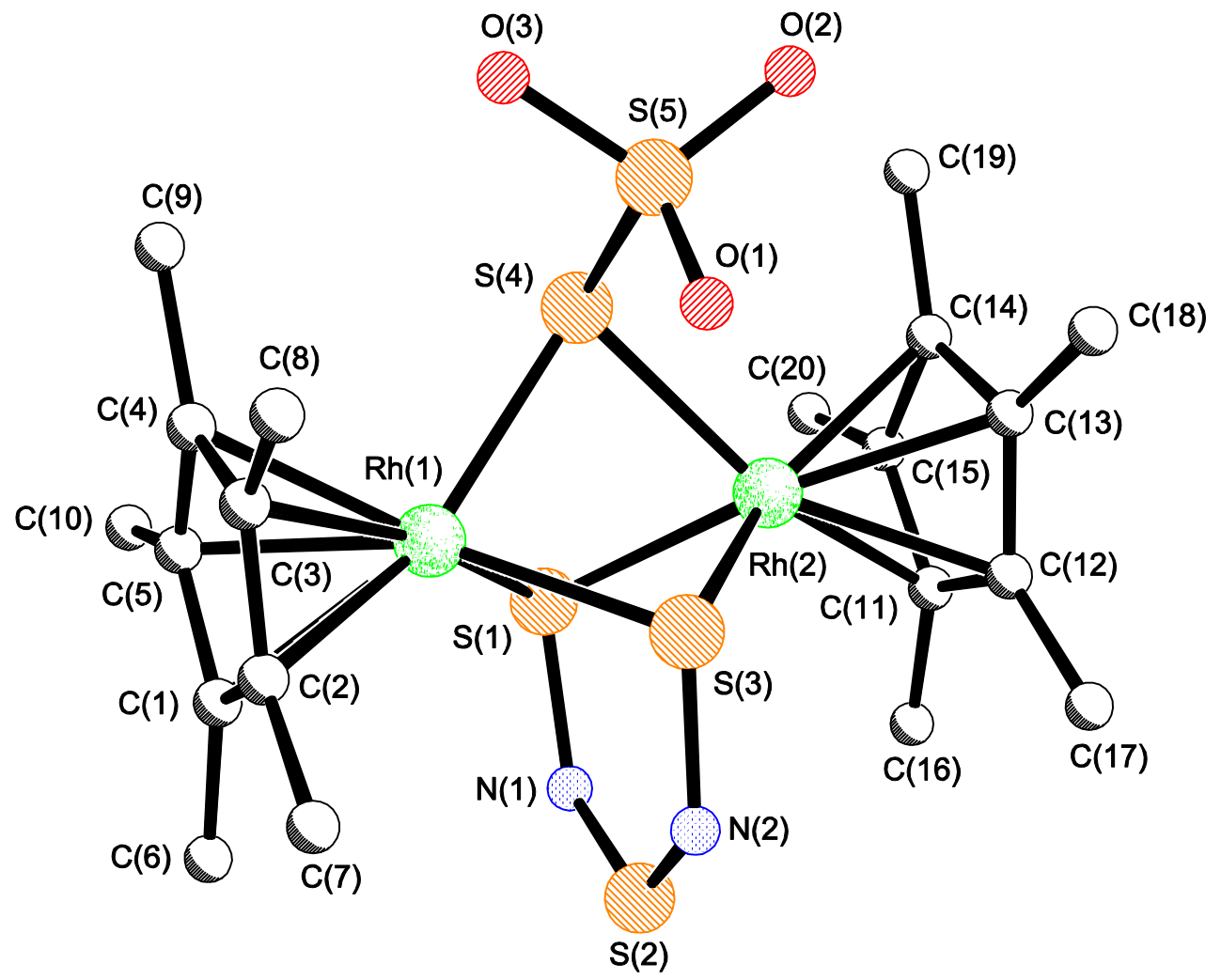

Figure 5. The crystal structure of 9

The molecule has approximate non-crystallographic $C_{\mathrm{s}}$ symmetry. The $\mathrm{Cp}^{*}$ rings in $\mathbf{9}$ are in an eclipsed position and the distance between the two Rh atoms is 3.1347(17) $\AA$ (Table S3 in Supporting Information). Both the $\left[\mathrm{S}_{3} \mathrm{~N}_{2}\right]^{2-}$ ligand and the two $\mathrm{S}$ atoms of the thiosulfate anion lie in one plane that is parallel to the planes of the $\mathrm{Cp}^{*}$ rings and is bisecting the distance between them. The three $\mathrm{Rh}-\mathrm{S}-\mathrm{Rh}$ planes can be labelled according to the sulfur atoms as $\sigma_{1}, \sigma_{3}$ and $\sigma_{4}$ (Figure 6a). The distribution of the planes is influenced by steric hindrance of the bridging ligands. The angles between $\sigma_{1}$ and $\sigma_{3}$, and between $\sigma_{3}$ and $\sigma_{4}$ are both ca. $122.5^{\circ}$. The former is determined by the steric demands of the $\left[\mathrm{S}_{3} \mathrm{~N}_{2}\right]^{2-}$ ligand, the latter by the interference of the $\left[\mathrm{S}_{2} \mathrm{O}_{3}\right]^{2-}$ anion with $\mathrm{S}(3)$ (Figure $6 \mathrm{~b}$ ). There is no steric hindrance between the planes $\sigma_{4}$ and $\sigma_{1}$ and thus the angle between them is only $115.0^{\circ}$. The structure of the $\left[\mathrm{S}_{3} \mathrm{~N}_{2}\right]^{2-}$ ligand is analogous to that in the palladium compounds prepared earlier. ${ }^{[22]}$ The $S(4)-S(5)$ distance in the bridging thiosulfate anion is 2.163(5) $\AA$ which is in good agreement with the values published for thiosulfate anions in $\left[\mathrm{Cp}^{*}{ }_{2} \mathrm{M}_{2}\left(\mu-\mathrm{S}_{2}\right)(\mu-\mathrm{S})\left(\mu-\mathrm{SSO}_{3}\right)\right](\mathrm{M}=\mathrm{Cr}, \mathrm{Mo}){ }^{[23]}$ 


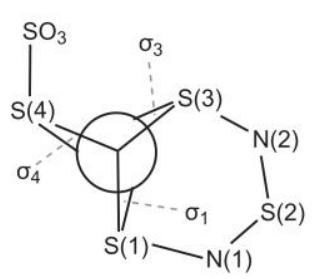

a

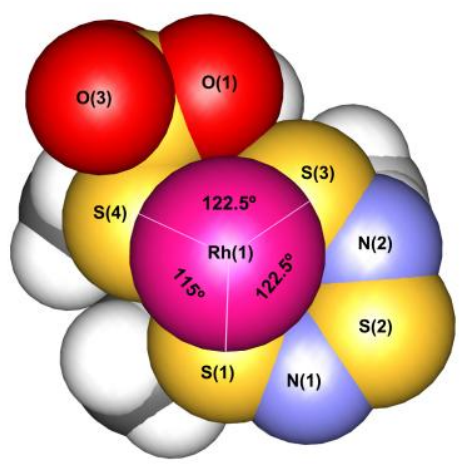

b

Figure 6. The central section of a molecule of 9 displayed by Newman projection along the $\mathrm{Rh}(1)-\mathrm{Rh}(2)$ axis (a) and a spacefill model along the same axis showing the interference of $\mathrm{O}(1)$ and $\mathrm{S}(3)$ (b); the front $\mathrm{Cp}^{*}$ ring is omitted for clarity.

From both the experimental and computational results several conclusions can be drawn about the influence of the $\mathrm{Cp} / \mathrm{Cp}^{*}$ ligand and the metal centre on the structure and bonding of $\mathrm{CpM}\left(\mathrm{S}_{2} \mathrm{~N}_{2}\right)$ and $\mathrm{Cp} * \mathrm{M}\left(\mathrm{S}_{2} \mathrm{~N}_{2}\right)$. The solid-state molecular geometry of $\mathbf{2}$ is similar to that of the $\mathrm{Cp}$ analogue $\mathbf{1},{ }^{[14]}$ however, the overall size of a molecule of $\mathbf{2}$ appears to be larger than that of a molecule of $\mathbf{1}$ (Table 1).

Table 1. Selected experimental and calculated bond lengths $(\AA)$ and angles $\left(^{\circ}\right)$ and Wiberg bond orders $b$ of compounds $\mathbf{1}-\mathbf{6}$

\begin{tabular}{|c|c|c|c|c|c|c|c|}
\hline & \multicolumn{3}{|c|}{1} & \multicolumn{2}{|c|}{3} & \multicolumn{2}{|c|}{5} \\
\hline & X-ray ${ }^{[14]}$ & $\mathrm{DFT}^{\text {[a] }}$ & $b$ & $\mathrm{DFT}^{\mathrm{al}}$ & $b$ & $\mathrm{DFT}^{[\mathrm{a}]}$ & $b$ \\
\hline $\mathrm{M}(1)-\mathrm{N}(1)$ & $1.816(1)$ & 1.792 & 0.72 & 1.931 & 0.74 & 1.933 & 0.81 \\
\hline $\mathrm{N}(1)-\mathrm{S}(1)$ & $1.556(1)$ & 1.558 & 1.49 & 1.562 & 1.48 & 1.573 & 1.42 \\
\hline $\mathrm{S}(1)-\mathrm{N}(2)$ & $1.597(2)$ & 1.600 & 1.25 & 1.594 & 1.26 & 1.592 & 1.28 \\
\hline $\mathrm{N}(2)-\mathrm{S}(2)$ & $1.657(2)$ & 1.646 & 1.19 & 1.648 & 1.18 & 1.651 & 1.16 \\
\hline $\mathrm{S}(2)-\mathrm{M}(1)$ & $2.0764(6)$ & 2.102 & 0.79 & 2.215 & 0.81 & 2.216 & 0.87 \\
\hline $\mathrm{M}(1)-\mathrm{C}(1)$ & $2.037(2)$ & - & 0.23 & - & 0.24 & - & 0.27 \\
\hline $\mathrm{M}(1)-\mathrm{C}(2)$ & $2.042(2)$ & - & 0.27 & - & 0.29 & - & 0.34 \\
\hline $\mathrm{M}(1)-\mathrm{C}(3)$ & $2.076(2)$ & - & 0.23 & - & 0.24 & - & 0.27 \\
\hline $\mathrm{M}(1)-\mathrm{C}(4)$ & $2.065(2)$ & - & 0.23 & - & 0.24 & - & 0.27 \\
\hline$M(1)-C(5)$ & $2.044(2)$ & - & 0.27 & - & 0.29 & - & 0.34 \\
\hline $\mathrm{Cp} / \mathrm{Cp} *-\mathrm{M}(1)$ & $1.662(2)$ & 1.649 & - & 1.810 & - & 1.815 & - \\
\hline $\mathrm{M}(1)-\mathrm{N}(1)-\mathrm{S}(1)$ & $118.32(8)$ & 119.9 & - & 120.0 & - & 120.3 & - \\
\hline $\mathrm{N}(1)-\mathrm{S}(1)-\mathrm{N}(2)$ & $112.04(7)$ & 110.7 & - & 112.0 & - & 111.6 & - \\
\hline $\mathrm{S}(1)-\mathrm{N}(2)-\mathrm{S}(2)$ & $111.22(8)$ & 112.2 & - & 114.0 & - & 114.0 & - \\
\hline $\mathrm{N}(2)-\mathrm{S}(2)-\mathrm{M}(1)$ & $107.40(5)$ & 106.6 & - & 107.4 & - & 107.7 & - \\
\hline $\mathrm{S}(2)-\mathrm{M}(1)-\mathrm{N}(1)$ & $91.02(5)$ & 90.5 & - & 86.6 & - & 86.3 & - \\
\hline
\end{tabular}

[a] Bond lengths and angles were calculated at DFT/B1B95/6-311+G*/def-TZPP/ecp level of theory

Table 1. continued. 


\begin{tabular}{|c|c|c|c|c|c|c|c|c|}
\hline & \multicolumn{3}{|c|}{2} & \multicolumn{2}{|c|}{4} & \multicolumn{3}{|c|}{6} \\
\hline & X-ray & DFT $^{\lfloor a\rfloor}$ & $b$ & $\mathrm{DFT}^{\lfloor\mathrm{a}\rfloor}$ & $b$ & X-ray & $\mathrm{DFT}^{\lfloor\mathrm{a}\rfloor}$ & $b$ \\
\hline $\mathrm{M}(1)-\mathrm{N}(1)$ & $1.8780(19)$ & 1.801 & 0.66 & 1.944 & 0.69 & $1.963(3)$ & 1.944 & 0.76 \\
\hline $\mathrm{N}(1)-\mathrm{S}(1)$ & $1.594(2)$ & 1.559 & 1.48 & 1.561 & 1.47 & $1.562(4)$ & 1.571 & 1.42 \\
\hline $\mathrm{S}(1)-\mathrm{N}(2)$ & $1.634(2)$ & 1.596 & 1.27 & 1.589 & 1.28 & $1.583(4)$ & 1.589 & 1.29 \\
\hline $\mathrm{N}(2)-\mathrm{S}(2)$ & $1.718(2)$ & 1.657 & 1.16 & 1.660 & 1.15 & $1.682(3)$ & 1.661 & 1.14 \\
\hline$S(2)-M(1)$ & $2.1371(7)$ & 2.106 & 0.74 & 2.228 & 0.77 & 2.1891(12) & 2.225 & 0.84 \\
\hline $\mathrm{M}(1)-\mathrm{C}(1)$ & $2.113(2)$ & - & 0.23 & - & 0.24 & $2.201(4)$ & - & 0.27 \\
\hline $\mathrm{M}(1)-\mathrm{C}(2)$ & $2.108(2)$ & - & 0.27 & - & 0.30 & $2.194(4)$ & - & 0.35 \\
\hline $\mathrm{M}(1)-\mathrm{C}(3)$ & $2.113(2)$ & - & 0.23 & - & 0.24 & $2.177(4)$ & - & 0.26 \\
\hline $\mathrm{M}(1)-\mathrm{C}(4)$ & $2.126(2)$ & - & 0.23 & - & 0.24 & $2.198(4)$ & - & 0.28 \\
\hline $\mathrm{M}(1)-\mathrm{C}(5)$ & $2.106(2)$ & - & 0.27 & - & 0.30 & $2.192(4)$ & - & 0.33 \\
\hline $\mathrm{Cp} / \mathrm{Cp}^{*}-\mathrm{M}(1)$ & $1.703(2)$ & 1.634 & - & 1.792 & - & $1.819(4)$ & 1.803 & - \\
\hline $\mathrm{M}(1)-\mathrm{N}(1)-\mathrm{S}(1)$ & $117.83(11)$ & 119.2 & - & 119.4 & - & $118.59(19)$ & 119.9 & - \\
\hline $\mathrm{N}(1)-\mathrm{S}(1)-\mathrm{N}(2)$ & $112.75(11)$ & 111.4 & - & 112.8 & - & $113.67(17)$ & 112.2 & - \\
\hline$S(1)-N(2)-S(2)$ & $111.27(12)$ & 112.3 & - & 114.2 & - & $112.7(2)$ & 114.0 & - \\
\hline $\mathrm{N}(2)-\mathrm{S}(2)-\mathrm{M}(1)$ & $106.86(8)$ & 106.2 & - & 106.8 & - & $108.13(13)$ & 107.4 & - \\
\hline $\mathrm{S}(2)-\mathrm{M}(1)-\mathrm{N}(1)$ & $91.29(6)$ & 90.9 & - & 86.8 & - & $86.94(11)$ & 86.4 & - \\
\hline
\end{tabular}

[a] Bond lengths and angles were calculated at DFT/B1B95/6-311+G*/def-TZPP/ecp level of theory

The distance between the Cp* ring and the Co atom in 2 is 1.703(2) $\AA$ ( $c f .1 .662(2) \AA$ between Cp and Co in 1). ${ }^{[14]}$ Also, all bond lengths in the $\operatorname{Co}\left(\mathrm{S}_{2} \mathrm{~N}_{2}\right)$ ring are approximately $0.05 \AA$ longer in $\mathbf{2}$ than in $\mathbf{1}$ and the $\mathrm{S}-\mathrm{Co}-\mathrm{N}$ angle is approximately $0.3^{\circ}$ larger in $\mathbf{2}$ than in $\mathbf{1}$. The results of the calculations (Table 1) suggest that this size increase is a crystal effect, as the calculated geometry of $\mathbf{2}$ is almost identical to that of 1 . The bond lengths in the $\operatorname{Co}\left(S_{2} \mathrm{~N}_{2}\right)$ ring differ by no more than $0.011 \AA$. The calculated $\mathrm{Cp} / \mathrm{Cp}^{*}-\mathrm{Co}$ distances show an opposite trend to the experimental ones: the $\mathrm{Cp}^{*-}$-Co distance in 2 is shorter by $0.015 \AA$ than the $\mathrm{Cp}-\mathrm{Co}$ distance in $\mathbf{1}$. The difference between these distances is considerably smaller than between the two experimental ones. The observation regarding the $\mathrm{S}-\mathrm{Co}-\mathrm{N}$ angle is also found in the calculated data, as the value in $\mathbf{2}$ is approximately $0.4^{\circ}$ larger than in $\mathbf{1}$.

Comparison of the calculated geometries of the rhodium and complexes $\mathbf{3}$ and $\mathbf{4}$, for which no X-ray diffraction data exist, shows that the structures are very similar, in accordance with what was found for $\mathbf{1}$ and 2. The maximum difference in bond lengths in the heterocycle is just $0.013 \AA$ and the $\mathrm{Cp}^{*}$ ring sits closer to the rhodium atom than the $\mathrm{Cp}$ ring by $0.018 \AA$. The $\mathrm{S}-\mathrm{Rh}-\mathrm{N}$ angles differ by no more than $0.2^{\circ}$. When the iridium complexes $\mathbf{5}$ and $\mathbf{6}$ are compared, similar conclusions can be drawn: the largest difference in bond length in the heterocycle is $0.011 \AA$, the $\mathrm{Cp}^{*}$ ring sits closer to the iridium atom by $0.012 \AA$ and the $\mathrm{S}-\mathrm{Ir}-\mathrm{N}$ angles are virtually identical. .

The calculations revealed an increase of the ring-to-metal distance when $\mathrm{Cp}^{*}$ is replaced by $\mathrm{Cp}$. This trend was further investigated by means of Wiberg carbon-metal bond orders, which are a measure of strength of the ring-metal bond (Table 1). The differences between the bond order values 
of the corresponding $\mathrm{Cp} / \mathrm{Cp}^{*}$ pairs are negligible suggesting that such a ring replacement causes a very small reduction in bonding.

The experimental bond lengths and angles in $\mathbf{2}$ and $\mathbf{6}$ reveal the influence of different van der Waals radii of the metal centres on the structure of the $M\left(S_{2} N_{2}\right)$ rings (Table 1). The bonds between the metal centre and $\mathrm{N}(1)$ and $\mathrm{S}(2)$ are considerably shorter in $\mathbf{2}$. The remaining bonds within the $\left(\mathrm{S}_{2} \mathrm{~N}_{2}\right)$ moiety are longer in 2 than in 6. The differences in the bond lengths $M-N(1)$ and $M-S(2)$ are directly linked to the value of the angle $\mathrm{S}(2)-\mathrm{M}-\mathrm{N}(1)$. In 2 , where the bonds coming from the metal centre are shorter, the angle is more obtuse than in 6, where the longer distances between the metal centre and $\mathrm{N}(1)$ and $\mathrm{S}(2)$ accompany a more acute angle. Analysis of the calculated geometrical data of 1, 3 and 5 brings further insight into the influence of the metal. In the series $\mathbf{1} \rightarrow \mathbf{3} \rightarrow \mathbf{5}$ the elongation of the $\mathrm{Cp}-$ $\mathrm{M}, \mathrm{M}-\mathrm{S}(2)$ and $\mathrm{M}-\mathrm{N}(1)$ bonds can be clearly seen, as well as the reduction of the $\mathrm{S}(2)-\mathrm{M}-\mathrm{N}(1)$ angle. In addition, the $\mathrm{S}(2)-\mathrm{N}(2)$ and $\mathrm{S}(1)-\mathrm{N}(1)$ bond lengths increase slightly (by 0.005 and $0.015 \AA$, respectively) while the $\mathrm{N}(2)-\mathrm{S}(1)$ distance becomes slightly shorter (by $0.008 \AA$ ). As a result of this electron density reshuffling due to the change of the metal atom, the shortest $\mathrm{S}(1)-\mathrm{N}(1)$ bond has become longer while the medium $\mathrm{N}(2)-\mathrm{S}(1)$ bond has become shorter. This is indicative of a slight increase in electron delocalisation in the heterocyclic ring when going from cobalt to iridium. The Wiberg bond orders support this conclusion. In the direction from cobalt to iridium the $\mathrm{M}-\mathrm{S}(2)$ and $\mathrm{M}-$ $\mathrm{N}(1)$ bonds are slightly stronger. At the same time, $\mathrm{S}(2)-\mathrm{N}(2)$ and $\mathrm{S}(1)-\mathrm{N}(1)$ become weaker, and $\mathrm{N}(2)-\mathrm{S}(1)$ becomes stronger. The $\mathrm{M}-\mathrm{S}(2)$ and $\mathrm{M}-\mathrm{N}(1)$ bonds are generally somewhat weaker than the three sulfur-nitrogen bonds.

\subsection{NMR spectra}

The NMR data of all the Cp* complexes are summarised in Table 2. In the ${ }^{1} \mathrm{H}$ NMR spectra, the five methyl groups in the $\mathrm{Cp} * \mathrm{M}\left(\mathrm{S}_{2} \mathrm{~N}_{2}\right)$ complexes give singlets that are significantly deshielded with respect to the signals of the starting materials, which enables a reliable identification of the products in

the reaction mixtures. The ${ }^{1} \mathrm{H}$ NMR signals of the $\mathrm{Cp}^{*}$ rings of the title complexes $\mathbf{2}, \mathbf{4}$ and $\mathbf{6}$ show a trend of increased deshielding when going from Co to Ir.

In accord with expectations, the ${ }^{13} \mathrm{C}$ NMR spectra of the $\mathrm{Cp} *$ complexes showed two signals for every $\mathrm{Cp}^{*}$ ring: one due to the $\mathrm{CH}_{3}$ groups and the other due to the aromatic $\mathrm{C}_{5}$ ring. Since ${ }^{103} \mathrm{Rh}$ has nuclear spin $I=1 / 2$, the $\mathrm{C}_{5}$ signals in the $\mathrm{Rh}$ complexes are split into doublets with small ${ }^{103} \mathrm{Rh}-{ }^{13} \mathrm{C}$ coupling constants. 
Table 2. NMR data for complexes, $2, \mathbf{4}, \mathbf{6}, \mathbf{7}, \mathbf{8}$ and $\mathbf{9}^{[\mathrm{a}]}$

\begin{tabular}{|c|c|c|c|c|c|}
\hline & $\delta(\mathrm{ppm})$ & $\begin{array}{l}{ }^{1} \mathrm{H} \text { NMR } \\
\quad \text { assignment } \\
\end{array}$ & $\delta(\mathrm{ppm})$ & $\begin{array}{c}{ }^{13} \mathrm{C} \mathrm{NMR} \\
\text { assignment }\end{array}$ & ${ }^{1} J_{103 \mathrm{Rh}^{-13} \mathrm{C}}$ \\
\hline 2 & 1.98 & $\mathrm{~s}, 15 \mathrm{H}, 5 \times \mathrm{CH}_{3}$ & $\begin{array}{l}10.80 \\
94.80\end{array}$ & $\begin{array}{l}\mathrm{s}, 5 \mathrm{C}, 5 \times \mathrm{CH}_{3} \\
\text { s, } 5 \mathrm{C}, \mathrm{C}_{5}\end{array}$ & \\
\hline 4 & 2.07 & $\mathrm{~s}, 15 \mathrm{H}, 5 \times \mathrm{CH}_{3}$ & $\begin{array}{c}9.26 \\
94.94\end{array}$ & $\begin{array}{l}\mathrm{s}, 5 \mathrm{C}, 5 \times \mathrm{CH}_{3} \\
\text { d, } 5 \mathrm{C}, \mathrm{C}_{5}\end{array}$ & $8.30 \mathrm{~Hz}$ \\
\hline 6 & 2.22 & $\mathrm{~s}, 15 \mathrm{H}, 5 \times \mathrm{CH}_{3}$ & $\begin{array}{l}10.70 \\
95.57\end{array}$ & $\begin{array}{l}\text { s, } 5 \mathrm{C}, 5 \times \mathrm{CH}_{3} \\
\text { s, } 5 \mathrm{C}, \mathrm{C}_{5}\end{array}$ & \\
\hline 7 & 1.79 & $\mathrm{~s}, 15 \mathrm{H}, 5 \times \mathrm{CH}_{3}$ & $\begin{array}{c}8.73 \\
98.52\end{array}$ & $\begin{array}{l}\text { s, } 10 \mathrm{C}, 10 \times \mathrm{CH}_{3} \\
\text { d, } 10 \mathrm{C}, 2 \times \mathrm{C}_{5}\end{array}$ & $7.27 \mathrm{~Hz}$ \\
\hline 8 & $\begin{array}{l}1.57 \\
2.17\end{array}$ & $\begin{array}{l}\mathrm{s}, 15 \mathrm{H}, 5 \times \mathrm{CH}_{3}\left(\mathrm{Cp}^{*} \operatorname{IrCl}_{2}\right)^{[\mathrm{b}]} \\
\mathrm{s}, 15 \mathrm{H}, 5 \times \mathrm{CH}_{3}\left(\mathrm{Cp}^{*} \operatorname{Ir}\left(\mathrm{S}_{2} \mathrm{~N}_{2}\right)\right)\end{array}$ & $\begin{array}{c}9.10 \\
10.73 \\
86.46 \\
97.13\end{array}$ & $\begin{array}{l}\mathrm{s}, 5 \mathrm{C}, 5 \times \mathrm{CH}_{3}\left(\mathrm{Cp}^{*} \operatorname{IrCl}_{2}\right) \\
\mathrm{s}, 5 \mathrm{C}, 5 \times \mathrm{CH}_{3}\left(\mathrm{Cp}^{*} \operatorname{Ir}\left(\mathrm{S}_{2} \mathrm{~N}_{2}\right)\right) \\
\mathrm{s}, 5 \mathrm{C}, \mathrm{C}_{5}\left(\mathrm{Cp}^{*} \operatorname{IrCl} \mathrm{I}_{2}\right) \\
\mathrm{s}, 5 \mathrm{C}, \mathrm{C}_{5}\left(\mathrm{Cp} * \operatorname{Ir}\left(\mathrm{S}_{2} \mathrm{~N}_{2}\right)\right)\end{array}$ & \\
\hline 9 & 1.66 & s, $15 \mathrm{H}, 5 \times \mathrm{CH}_{3}$ & $\begin{array}{c}8.67 \\
99.56\end{array}$ & $\begin{array}{l}\mathrm{s}, 10 \mathrm{C}, 10 \times \mathrm{CH}_{3} \\
\mathrm{~d}, 10 \mathrm{C}, 2 \times \mathrm{C}_{5}\end{array}$ & $7.27 \mathrm{~Hz}$ \\
\hline
\end{tabular}

[a] Spectra measured in $\mathrm{CDCl}_{3}$. The ${ }^{1} \mathrm{H}$ NMR chemical shifts are calibrated to the peak of residual $\mathrm{CHCl}_{3}(7.26 \mathrm{ppm}) .{ }^{[24]}$

[b] The assignment of the spectra of $\mathbf{8}$ follows from the known chemical shifts for both $\left[\mathrm{Cp}^{*} \operatorname{IrCl}_{2}\right]_{2}$ and $\mathrm{Cp} * \operatorname{Ir}\left(\mathrm{S}_{2} \mathrm{~N}_{2}\right)$.

\subsection{IR and Raman spectroscopy}

The majority of the IR bands are due to the $\mathrm{Cp}^{*}$ moieties. Spectra of all the compounds show characteristic $\mathrm{C}-\mathrm{H}$ stretches in the area $3000-2900 \mathrm{~cm}^{-1}$ and $\mathrm{CH}_{3}$ deformation vibrations between 1460 and $1370 \mathrm{~cm}^{-1}$.

The IR frequencies in the spectrum of $\mathbf{2}$ matched well with the published values. ${ }^{[4]}$ The IR spectra of $\mathbf{4}$ closely match with those of $\mathbf{2}$ and $\mathbf{6}$, which supports the existence of the five-membered $\mathrm{Rh}\left(\mathrm{S}_{2} \mathrm{~N}_{2}\right)$ ring in 4. The intense bands at $724(2)$ and $700 \mathrm{~cm}^{-1}(\mathbf{4}, \mathbf{6})$, and at $646(\mathbf{4})$ and $635 \mathrm{~cm}^{-1}(\mathbf{2}, \mathbf{6})$ are the most characteristic modes observed also in a number of other metalladithiadiazoles. ${ }^{[25]}$

It seems reasonable to assign the Raman lines at $919,649,426$ and $403 \mathrm{~cm}^{-1}$ in the spectra of 4 to the $\mathrm{Rh}\left(\mathrm{S}_{2} \mathrm{~N}_{2}\right)$ ring vibrational modes. The wavenumbers correspond well with those at $864,639,419$ and $385 \mathrm{~cm}^{-1}$ found in the spectrum of $\mathbf{6}$. It is noteworthy that the lines in the spectrum of $\mathbf{6}$ are generally shifted towards lower wavenumbers.

\section{Conclusion}

We have prepared 5-( $\eta^{5}$-pentamethylcyclopentadienyl)-5,1,3,2,4-rhodiadithiadiazole (4) from [Cp* $\left.\mathrm{RhCl}_{2}\right]_{2}$ by two reproducible methods. The first synthetic route uses the $\left[\mathrm{S}_{4} \mathrm{~N}_{3}\right] \mathrm{Cl} / \mathrm{NH}_{3}$ (1) reaction system, the other takes advantage of the ligand exchange with the versatile tin reagent $\left[n \mathrm{Bu}_{2} \mathrm{Sn}\left(\mathrm{S}_{2} \mathrm{~N}_{2}\right)\right]_{2}$. 
4 is a microcrystalline substance which does not crystallise into well-grown single crystals or crystals of sufficient size to be investigated by powder X-ray diffraction. 4 was characterised by ${ }^{1} \mathrm{H}$ and ${ }^{13} \mathrm{C}$ NMR spectroscopy, mass spectrometry and its constitution was supported by vibrational spectra. 4 is air-sensitive and partially hydrolyses into 9 , which contains the $\left[\mathrm{S}_{3} \mathrm{~N}_{2}\right]^{2-}$ and $\left[\mathrm{S}_{2} \mathrm{O}_{3}\right]^{2-}$ bridging ligands in one molecule.

The low-temperature crystal structure of $\mathbf{2}$ was determined. The comparison of the solid-state structures of both 1 and $\mathbf{2}$ showed insignificant differences between the two molecules and quantum chemical calculations suggested that the larger size of the molecule of $\mathbf{2}$ is a result of crystal effects.

A thorough comparison of the calculated structures has been carried out between the nonmethylated and methylated pairs of cyclopentadienylmetalladithiadiazoles. The crystal structures of 1 and 2 reveal an increased ring-metal distance in 2, while the calculated structures show an opposite trend. The Wiberg bond order analysis demonstrated that substitution of a $\mathrm{Cp}$ ring with a $\mathrm{Cp}^{*}$ ring has a very small effect on the bonding between the ring and the metal centre. The calculations, supported by the low-temperature X-ray structures of $\mathbf{1},{ }^{[14]} \mathbf{2}$ and $\mathbf{6}$, indicate an increasing degree of $\pi$-electron delocalisation in the $\mathrm{M}\left(\mathrm{S}_{2} \mathrm{~N}_{2}\right)$ heterocycle when going from Co to Ir.

\section{Experimental Section}

Unless otherwise stated, all reactions were carried out in an oxygen-free nitrogen atmosphere using standard Schlenk and syringe techniques. Solvents were dried, purified and stored according to common procedures. ${ }^{[26]} \mathrm{RhCl}_{3} \cdot \mathrm{xH}_{2} \mathrm{O}$ and $\mathrm{IrCl}_{3} \cdot \mathrm{xH}_{2} \mathrm{O}$ were obtained on loan from Johnson Matthey Plc. Compounds $\mathrm{S}_{4} \mathrm{~N}_{4},{ }^{[27]}\left[\mathrm{S}_{4} \mathrm{~N}_{3}\right] \mathrm{Cl},{ }^{[28]} \mathrm{Cp} * \mathrm{Co}(\mathrm{CO})_{2},{ }^{[29]}\left[\mathrm{Cp}^{*} \mathrm{RhCl}_{2}\right]_{2},{ }^{[30]}\left[\mathrm{Cp}^{*} \mathrm{IrCl}_{2}\right]_{2},{ }^{[30]}\left[n \mathrm{Bu}_{2} \mathrm{Sn}\left(\mathrm{S}_{2} \mathrm{~N}_{2}\right)\right]_{2}{ }^{[6]}$ and $2^{[4]}$ were prepared according to published methods. 6 was prepared by the published procedure but the reactants were mixed in their $\mathrm{CH}_{2} \mathrm{Cl}_{2}$ solutions. ${ }^{[6]}{ }^{1} \mathrm{H}$ and ${ }^{13} \mathrm{C}$ NMR spectra were recorded on a Jeol GSX $270 \mathrm{MHz}$ spectrometer with $\delta$ referenced to external tetramethylsilane. All ${ }^{13} \mathrm{C}$ NMR spectra are

proton-decoupled. ${ }^{14} \mathrm{~N}$ NMR spectra were recorded on a Bruker Avance II 400 spectrometer with $\delta$ referenced to external liquid ammonia. Mass spectrometry was performed by the University of St Andrews Mass Spectrometry Service and elemental analyses were performed by the St Andrews University School of Chemistry Service. The elemental analysis data could not be obtained with better accuracy due to air-sensitivity of the compounds. IR spectra were recorded as pressed $\mathrm{KBr}$ discs on a Perkin-Elmer 2000 FT/IR/Raman spectrometer. Raman spectra of neat materials were recorded in glass 
capillaries in the range $3500-100 \mathrm{~cm}^{-1}$ using the same spectrometer. Powder X-ray diffraction patterns were recorded on a Stoe STADI/P diffractometer using $\mathrm{Cu}-K_{\alpha_{1}}$ radiation.

\section{X-ray structure determination}

Crystal structure data were collected at $93 \mathrm{~K}$ on a Rigaku MM007 confocal optics/Saturn CCD diffractometer using Mo- $K_{\alpha}$ radiation (confocal optic, $\lambda=0.71073 \AA$ ), and corrected for absorption.

The structure was solved by direct methods and refined by full-matrix least-squares methods on $F^{2}$ values of all data. Refinements were performed using SHELXTL (Version 6.1, Bruker-AXS, Madison WI, USA, 2001). The experimental details including the results of the refinement are given in Table 3.

Table 3. Crystallographic data for compounds $2,6,8 \cdot n \mathrm{Bu}_{2} \mathrm{SnCl}_{2}$ and $9 \cdot \mathrm{CH}_{2} \mathrm{Cl}_{2}$

\begin{tabular}{|c|c|c|c|c|}
\hline Compound & 2 & 6 & 8. $n \mathrm{Bu}_{2} \mathrm{SnCl}_{2}$ & 9. $\mathrm{CH}_{2} \mathrm{Cl}_{2}$ \\
\hline Empirical formula & $\mathrm{C}_{10} \mathrm{H}_{15} \mathrm{CoN}_{2} \mathrm{~S}_{2}$ & $\mathrm{C}_{10} \mathrm{H}_{15} \mathrm{IrN}_{2} \mathrm{~S}_{2}$ & $\mathrm{C}_{31.5} \mathrm{H}_{52} \mathrm{Cl}_{4} \mathrm{Ir}_{2} \mathrm{~N}_{2} \mathrm{~S}_{2} \mathrm{Sn}$ & $\mathrm{C}_{21} \mathrm{H}_{32} \mathrm{Cl}_{2} \mathrm{~N}_{2} \mathrm{O}_{3} \mathrm{Rh}_{2} \mathrm{~S}_{5}$ \\
\hline Formula weight & 286.29 & 419.56 & 1167.76 & 797.51 \\
\hline Temperature & $93(2) \mathrm{K}$ & 93(2) K & 93(2) K & 93(2) K \\
\hline Crystal colour, habit & purple plate & orange plate & red prism & red needle \\
\hline Crystal system & Monoclinic & Monoclinic & Triclinic & Monoclinic \\
\hline Space group & $P 2(1) / n$ & $P 2(1) / n$ & $P-1$ & $P 2(1) / c$ \\
\hline$a / \stackrel{\mathrm{A}}{2}$ & $8.1372(10)$ & $7.856(3)$ & $10.1044(8)$ & $10.615(3)$ \\
\hline 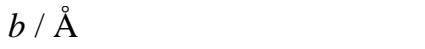 & $13.1558(16)$ & $13.129(5)$ & $12.1259(13)$ & $23.415(6)$ \\
\hline$c / \check{A}$ & $12.9834(16)$ & $12.860(13)$ & $16.8451(18)$ & $23.361(6)$ \\
\hline$\alpha /^{\circ}$ & 90 & 90 & $78.220(8)$ & 90 \\
\hline$\beta /^{\circ}$ & $104.008(7)$ & $103.39(3)$ & $80.344(8)$ & $90.089(4)$ \\
\hline$\gamma /{ }^{\circ}$ & 90 & 90 & $77.688(9)$ & 90 \\
\hline$U / \AA^{3}$ & $1348.6(3)$ & $1290.4(14)$ & $1957.3(3)$ & $5806(2)$ \\
\hline$Z$ & 4 & 4 & 2 & 8 \\
\hline$D c / \mathrm{Mg} \cdot \mathrm{m}^{-3}$ & 1.410 & 2.160 & 1.981 & 1.825 \\
\hline$\mu / \mathrm{mm}^{-1}$ & 1.554 & 10.641 & 7.819 & 1.708 \\
\hline$F(000)$ & 592 & 792 & 1118 & 3200 \\
\hline Measured reflections & 11599 & 7725 & 12710 & 43104 \\
\hline Observed indt reflections & 2372 & 2296 & 6883 & 9933 \\
\hline Final $R_{1}, \omega R_{2}[I>2 \sigma(I)]$ & $0.0342,0.0864$ & $0.0217,0.0416$ & $0.0220,0.0445$ & $0.1107,0.2688$ \\
\hline Largest diff. peak hole / e. $\stackrel{\mathrm{A}}{ }^{-3}$ & $0.401,-0.406$ & $1.051,-0.825$ & $1.145,-1.017$ & $3.386,-2.291$ \\
\hline
\end{tabular}

\section{Purification of $\mathrm{S}_{4} \mathbf{N}_{4}$}

CAUTION: $\mathrm{S}_{4} \mathrm{~N}_{4}$ explodes upon mechanical or heat shock. Its explosiveness increases with the purity of the substance. Kevlar gloves and visor should be used when manipulating with $\mathrm{S}_{4} \mathrm{~N}_{4}$. Residues of $\mathrm{S}_{4} \mathrm{~N}_{4}$ were disposed of by decomposition with aqueous $\mathrm{NaOH} .{ }^{[31]}$ 
The crude $\mathrm{S}_{4} \mathrm{~N}_{4} / \mathrm{S}_{8}$ mixture obtained from the dioxane extract ${ }^{[27]}$ contained a high amount of sulfur. A significant amount of sulfur was removed by suspending the $\mathrm{S}_{4} \mathrm{~N}_{4} / \mathrm{S}_{8}$ mixture in a sufficiently small amount of dichloromethane and subsequent decanting of the orange $\mathrm{S}_{4} \mathrm{~N}_{4}$-rich solution. The solvent was removed (rotary evaporator) and the $\mathrm{S}_{4} \mathrm{~N}_{4}$-rich crude mixture was recrystallised from toluene. The purity of $\mathrm{S}_{4} \mathrm{~N}_{4}$ was checked by TLC.

\subsection{Preparation of $\mathrm{Cp} * \mathrm{Rh}\left(\mathrm{S}_{2} \mathrm{~N}_{2}\right)(4)$ \\ The $\left[\mathrm{S}_{4} \mathbf{N}_{3}\right] \mathrm{Cl} / \mathrm{NH}_{3}(\mathbf{l})$ method}

Ammonia (20-30 mL) was condensed into a predried three-neck flask. $\left[\mathrm{S}_{4} \mathrm{~N}_{3}\right] \mathrm{Cl}(51 \mathrm{mg}, 0.247 \mathrm{mmol})$ was added in one portion. The mixture turned red immediately and was stirred for $30 \mathrm{~min}$. at $-78^{\circ} \mathrm{C}$. $\left[\mathrm{Cp}^{*} \mathrm{RhCl}_{2}\right]_{2}(153 \mathrm{mg}, 0.247 \mathrm{mmol})$ was added in one portion and the mixture was allowed to warm up to $-33^{\circ} \mathrm{C}$. Once the temperature was reached, the cooling bath in the ammonia condenser was regularly supplied with dry ice and the mixture was kept under cold reflux for $2 \mathrm{~h}$ until the colour of the mixture changed to dark purple with a slight greenish tint at the meniscus. After that period, the ammonia was allowed to evaporate spontaneously leaving a beige/brown mixture of solids. The mixture was put under high vacuum for $15 \mathrm{~min}$. to remove residual ammonia and after reintroduction of nitrogen gas it was extracted with just one portion of dry dichloromethane $(10 \mathrm{~mL})$. The extract was filtered through a sinter, the solvent was removed and the compound dried in high vacuum.

\section{The transmetallation using $\left[n \mathrm{Bu}_{2} \mathrm{Sn}\left(\mathrm{S}_{2} \mathrm{~N}_{2}\right)\right]_{2}$}

The tin reagent $(161 \mathrm{mg}, 0.247 \mathrm{mmol})$ was dissolved in dry dichloromethane $(30 \mathrm{~mL})$. A solution of $\left[\mathrm{Cp}^{*} \mathrm{RhCl}_{2}\right]_{2}(153 \mathrm{mg}, 0.247 \mathrm{mmol})$ in dry dichloromethane $(30 \mathrm{~mL})$ was added dropwise and the mixture was stirred for $6 \mathrm{~h}$ at room temperature. The solvent was evaporated, the crude product was adsorbed on a small amount of silica and added to a packed silica column $(25 \times 2 \mathrm{~cm})$. Unreacted starting material and the byproduct were removed with toluene as a pale yellow band. Elution with toluene/acetone $(2: 1)$ gave several similarly coloured fractions which had to be analysed by ${ }^{1} \mathrm{H}$ NMR so that the product could be identified. The residues were washed with toluene/acetone $(1: 1)$ but they contained only a small amount of very contaminated product and were not worth re-purifying. Yield 6 mg $(10 \%)$. Compound decomposed without melting at $190{ }^{\circ} \mathrm{C}$ (blackening). $\mathrm{C}_{10} \mathrm{H}_{15} \mathrm{RhS}_{2} \mathrm{~N}_{2}$ (330.28): calcd. C 36.4, H 4.6, N 8.5; found: C 36.4, H 5.0, N 6.1. MS(ES ${ }^{+}$TOF): $m / z 330.99(100 \%)[\mathrm{MH}]^{+} .{ }^{1} \mathrm{H}$ $\mathrm{NMR}\left(270 \mathrm{MHz}, \mathrm{CDCl}_{3}, 25^{\circ} \mathrm{C}\right): \delta=2.04$ (s, 15H, Cp*). ${ }^{13} \mathrm{C} \mathrm{NMR}\left(67.9 \mathrm{MHz}, \mathrm{CDCl}_{3}, 25^{\circ} \mathrm{C}\right): \delta=9.26$

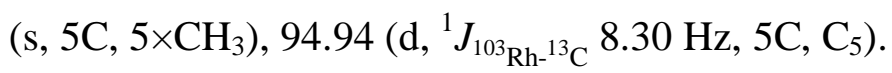

\subsection{Analytical data for $\left[\mathrm{Cp}^{*} \mathrm{RhCp} * \mathrm{Cl} \cdot \mathrm{H}_{2} \mathrm{O}(7)^{[18]}\right.$}


Yield 274 mg (67 \%). M.p. $182^{\circ} \mathrm{C} . \mathrm{C}_{20} \mathrm{H}_{32} \mathrm{RhClO}$ (426.83): calcd. C 56.3, H 7.6; found: C 57.3, H 7.6. MS(ES TOF): $m / z 373.05(100 \%)\left[\mathrm{Cp}^{*} \mathrm{RhCp}^{*}\right]^{+} .{ }^{1} \mathrm{H} \mathrm{NMR}\left(270 \mathrm{MHz}, \mathrm{CDCl}_{3}, 25{ }^{\circ} \mathrm{C}\right): \delta=1.77(\mathrm{~s}$, $\left.30 \mathrm{H}, 2 \mathrm{Cp}^{*}\right) .{ }^{13} \mathrm{C} \mathrm{NMR}\left(67.9 \mathrm{MHz}, \mathrm{CDCl}_{3}, 25{ }^{\circ} \mathrm{C}\right): \delta=8.73\left(\mathrm{~s}, 10 \mathrm{C}, 10 \times \mathrm{CH}_{3}\right), 98.52\left(\mathrm{~d},{ }^{1} J_{103} \mathrm{Rh}^{-13} \mathrm{C}^{13}=\right.$ 7.27 Hz, 10C, $\left.2 \times \mathrm{C}_{5}\right)$.

\subsection{Analytical data for $\left[C p^{*} R h\left(\mu-S_{3} N_{2}\right)\left(\mu-S_{2} O_{3}\right) R h C p^{*}\right](8)$}

Compound 8 decomposed without melting at $210^{\circ} \mathrm{C}$ (blackening). $\mathrm{C}_{20} \mathrm{H}_{30} \mathrm{Rh}_{2} \mathrm{~S}_{5} \mathrm{~N}_{2} \mathrm{O}_{3}$ (712.60): calcd. $\mathrm{C}$ 33.7, H 4.2, N 3.9; found: C 35.1, H 4.3, N 2.8. MS(ES ${ }^{+}$TOF): $m / z 734.62$ (100 \%) [MNa] 712.70 (5 \%) $[\mathrm{MH}]^{+} .{ }^{1} \mathrm{H}$ NMR $\left(270 \mathrm{MHz}, \mathrm{CDCl}_{3}, 25{ }^{\circ} \mathrm{C}\right): \delta=1.65\left(\mathrm{~s}, 30 \mathrm{H}, 2 \times \mathrm{Cp}^{*}\right) .{ }^{13} \mathrm{C} \mathrm{NMR}(67.9 \mathrm{MHz}$,

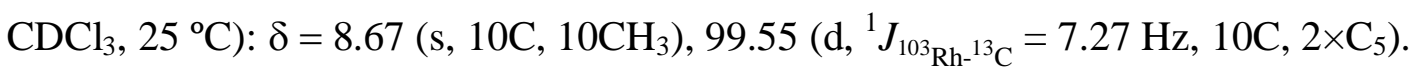

\subsection{Computational Details}

All calculations were performed on isolated molecules using Gaussian $03^{[32]}$ at the Density Functional (DFT) level of theory using the B1B95 ${ }^{[33]}$ functional, in combination with the $6-311+\mathrm{G}^{*}$ basis set as it is implemented in Gaussian 03 for hydrogen, carbon, nitrogen and sulfur. For cobalt, rhodium and iridium the def-TZVPP basis sets ${ }^{[34-36]}$ and Stuttgart ECPs from $1990^{[37,38]}$ were used. The geometries

of 1, 2, 3, 4 and 5 were calculated in $C_{\mathrm{s}}$ symmetry; the geometry of $\mathbf{6}$ was calculated in $C_{1}$ symmetry. Force-field calculations were used to ascertain whether the resulting structures were energy minima. All subsequent calculations of molecular properties were performed using the optimized geometries. Wiberg bond orders were calculated using the NBO 3.1 program $^{[39]}$ as it is implemented in the Gaussian 03 program package.

Supporting Information is available and contains the X-ray structure of $\left[\mathrm{Cp}^{*} \mathrm{RhCp} *\right] \mathrm{Cl}(7)$ (Figure $\mathrm{S} 1$ ), refinement data and list of selected bond lengths and angles for [Cp* $\mathrm{RhCp} * \mathrm{Cl}$ (7) (Tables $\mathrm{S} 1$ and $\mathrm{S} 2$ ), list of selected bond lengths and angles for $\mathrm{Cp} * \operatorname{Ir}\left[\mathrm{S}_{2} \mathrm{~N}_{2}\left(\mathrm{IrCl}_{2} \mathrm{Cp}^{*}\right)\right]$ (8) (Table S3) and list of selected bond lengths and angles for $\mathrm{Cp} * \mathrm{Rh}\left(\mu-\mathrm{S}_{3} \mathrm{~N}_{2}\right)\left(\mu-\mathrm{S}_{3} \mathrm{O}_{2}\right) \mathrm{RhCp}^{*}$ (9) (Table S4).

\section{Acknowledgements}

We wish to thank the Engineering and Physical Sciences Research Council (EPSRC) for funding (VM) and the University of Antwerp for access to the university's computer cluster CalcUA. We are grateful to Dr. Mikael P. Johansson for his assistance with the choice of the basis sets and core potentials for the transition metal atoms. 


\section{References}

[1] a) F. P. Burt, J. Chem. Soc., Trans. 1910, 97, 1171-1174; b) V. V. Walatka, Jr., M. M. Labes, J. H. Perlstein, Phys. Rev. Lett. 1973, 31, 1139-1142.

[2] a) T. Chivers, A Guide to Chalcogen-Nitrogen Chemistry, World Scientific Publishing Co. Pte. Ltd., Singapore, 2005 and references therein; b) G. Antorrena, S. Brownridge, T. S. Cameron, F. Palacio, S. Parsons, J. Passmore, L. K. Thompson, F. Zarlaida, Can. J. Chem. 2002, 80, 15681583 and references therein; c) H. Du, R. C. Haddon, I. Krossing, J. Passmore, J. M. Rawson, M. J. Schriver, Chem. Commun. 2002, 1836-1837 and references therein.

[3] F. Edelmann, J. Organomet. Chem. 1982, 228, C47-C50.

[4] G. Granozzi, M. Casarin, F. Edelmann, T. A. Albright, E. D. Jemmis, Organometallics 1987, 6, 2223-2227.

[5] R. T. Boeré, B. Klassen, K. H. Moock, J. Organomet. Chem. 1994, 467, 127-133.

[6] S. M. Aucott, A. M. Z. Slawin, J. D. Woollins, Can. J. Chem. 2002, 80, 1481-1487.

[7] S. Q. Niu, M. B. Hall, Chem. Rev. 2000, 100, 353-406.

[8] G. H. Loew, D. L. Harris, Chem. Rev. 2000, 100, 407-420.

[9] P. E. M. Siegbahn, M. R. A. Blomberg, Chem. Rev. 2000, 100, 421-438.

[10] G. Frenking, N. Frohlich, Chem. Rev. 2000, 100, 717-774.

[11] a) K. Tersago, V. Matuska, C. Van Alsenoy, A. M. Z. Slawin, J. D. Woollins, F. Blockhuys, Dalton Trans. 2007, 4529-4535; b) K. Tersago, C. Van Alsenoy, J. D. Woollins, F. Blockhuys, Chem. Phys. Lett. 2006, 423, 422-426.

[12] a) J. Van Droogenbroeck, K. Tersago, C. Van Alsenoy, S. M. Aucott, H. L. Milton, J. D. Woollins, F. Blockhuys, Eur. J. Inorg. Chem. 2004, 3798-3805; b) K. Tersago, J. Van Droogenbroeck, C. Van Alsenoy, W. A. Herrebout, B. J. van der Veken, S. M. Aucott, J. D. Woollins, F. Blockhuys, Phys. Chem. Chem. Phys. 2004, 6, 5140-5144.

[13] a) F. Blockhuys, S. L. Hinchley, A. Yu. Marakov, Yu. V. Gatilov, A. V. Zibarev, J. D. Woollins, D. W. H. Rankin, Chem. Eur. J. 2001, 7, 3592-3602; b) A. Yu. Makarov, I. Yu. Bagryanskaya, F. Blockhuys, C. Van Alsenoy, Yu. V. Gatilov, V. V. Knyazev, A. M. Maksimov, T. V. Mikhalina, V. E. Platonov, M. M. Shakirov, A. V. Zibarev, Eur. J. Inorg. Chem. 2003, 77-88.

[14] J. Van Droogenbroeck, C. Van Alsenoy, S. M. Aucott, J. D. Woollins, A. D. Hunter, F. Blockhuys, Organometallics 2005, 24, 1004-1011.

[15] T. Chivers, F. Edelmann, Polyhedron 1986, 5, 1661-1699. 
[16] a) I. P. Parkin, J. D. Woollins, P. S. Belton, J. Chem. Soc., Dalton Trans. 1990, 511; b) P. A. Bates, M. B. Hursthouse, P. F. Kelly, J. D. Woollins, J. Chem. Soc., Dalton Trans. 1986, 23672370; c) P. S. Belton, I. P. Parkin, D. J. Williams, J. D. Woollins, J. Chem. Soc., Chem. Commun. 1988, 1479-1480; d) C. A. O'Mahoney, I. P. Parkin, D. J. Williams, J. D. Woollins, J. Chem. Soc., Dalton Trans. 1989, 1179-1185; e) P. F. Kelly, J. D. Woollins, J. Chem. Soc., Dalton Trans. 1988, 1053-1057; f) I. P. Parkin, J. D. Woollins, J. Chem. Soc., Dalton Trans. 1990, 925-930.

[17] Although 7 is a known compound (see ref. [18]), its NMR data or X-ray structure have not been published to date. As the data published for other decamethylrhodiocenium salts (see ref. [19]) cannot be used for a precise comparison, we prepared 7, recorded its NMR spectra and determined its X-ray structure (see Supporting Information).

[18] U. Kölle, W. Kläui, Z. Naturforsch. B 1991, 46, 75-83.

[19] a) D. Buchholz, B. Gloaguen, J.-L. Fillaut, M. Cotrait, D. Astruc, Chem. Eur. J. 1995, 1, 374-381; b) D. Buchholz, L. Zsolnai, G. Huttner, D. Astruc, J. Organomet. Chem. 2000, 593-594, 494-496; c) O. V. Gusev, L. N. Morozova, T. A. Peganova, P. V. Petrovskii, N. A. Ustynyuk, P. M. Maitlis, J. Organomet. Chem. 1994, 472, 359-363; d) T. Steinke, C. Gemel, M. Cokoja, M. Wintner, R. A. Fischer, Dalton Trans. 2005, 55-62.

[20] A. Bondi, J. Phys. Chem. 1964, 68, 441-451.

[21] The list of bond lengths and angles is included in Supporting Information.

[22] a) U. Thewalt, Z. Naturforsch. B 1982, 37, 276-280; b) P. F. Kelly, A. M. Z. Slawin, D. J. Williams, J. D. Woollins, Polyhedron 1991, 10, 2337-2340; c) P. F. Kelly, A. M. Z. Slawin, A. Soriano-Rama, J. Chem. Soc., Dalton Trans. 1996, 53-59.

[23] a) A. Toupadakis, G. J. Kubas, C. J. Burns, Inorg. Chem. 1992, 31, 3810-3817; b) H. Brunner, U. Klement, J. Pfauntsch, J. Wachter, Angew. Chem. 1987, 99, 268-269; c) G. J. Kubas, R. R. Ryan, K. A. Kubat-Martin, J. Am. Chem. Soc. 1989, 111, 7823-7832.

[24] H. E. Gottlieb, V. Kotlyar, A. Nudelman, J. Org. Chem. 1997, 62, 7512-7515.

[25] J. D. Woollins, R. Grinter, M. K. Johnson, A. J. Thomson, J. Chem. Soc., Dalton Trans. 1980, 1910-1916.

[26] D. D. Perrin, W. L. F. Armarego, Purification of Laboratory Chemicals, 3rd ed., Pergamon Press plc, Oxford, UK, 1988.

[27] M. Villena-Blanco, W. L. Jolly, Inorg. Synth. 1967, 9, 98-102.

[28] W. L. Jolly, K. D. Maguire, Inorg Synth. 1967, 9, 102-111.

[29] S. A. Frith, J. L. Spencer, Inorg. Synth. 1990, 28, 273-280.

[30] C. White, A. Yates, P. M. Maitlis, Inorg. Synth. 1992, 29, 228-234. 
[31] Gmelin Handbook of Inorganic Chemistry, Sulfur-Nitrogen Compounds, Part 2, 8th ed., Springer Verlag, Berlin, Germany, 1985.

[32] M. J. Frisch, G. W. Trucks, H. B. Schlegel, G. E. Scuseria, M. A. Robb, J. R. Cheeseman, J. A. Montgomery, Jr., T. Vreven, K. N. Kudin, J. C. Burant, J. M. Millam, S. S. Iyengar, J. Tomasi, V. Barone, B. Mennucci, M. Cossi, G. Scalmani, N. Rega, G. A. Petersson, H. Nakatsuji, M. Hada, M. Ehara, K. Toyota, R. Fukuda, J. Hasegawa, M. Ishida, T. Nakajima, Y. Honda, O. Kitao, H. Nakai, M. Klene, X. Li, J. E. Knox, H. P. Hratchian, J. B. Cross, C. Adamo, J. Jaramillo, R. Gomperts, R. E. Stratmann, O. Yazyev, A. J. Austin, R. Cammi, C. Pomelli, J. W. Ochterski, P. Y. Ayala, K. Morokuma, G. A. Voth, P. Salvador, J. J. Dannenberg, V. G. Zakrzewski, S. Dapprich, A. D. Daniels, M. C. Strain, O. Farkas, D. K. Malick, A. D. Rabuck, K. Raghavachari, J. B. Foresman, J. V. Ortiz, A. Cui, A. G. Baboul, S. Clifford, J. Cioslowski, B. B. Stefanov, G. Liu, A. Liashenko, P. Piskorz, I. Komaromi, R. L. Martin, D. J. Fox, T. Keith, M. A. Al-Laham, C. Y. Peng, A. Nanayakkara, M. Challacombe, P. M. W. Gill, B. Johnson, W. Chen, M. W. Wong, C. Gonzalez, J. A. Pople, Gaussian 03, Revision C.02, Gaussian, Inc., Wallingford CT, 2004.

[33] A. D. Becke, J. Chem. Phys. 1996, 104, 1040-1046.

[34] A. Schäfer, C. Huber, R. Ahlrichs, J. Chem. Phys. 1994, 100, 5829-5835.

[35] A. J. H. Wachters, J. Chem. Phys. 1970, 52, 1033-1036.

[36] F. Weigend, M. Haser, H. Patzelt, R. Ahlrichs, Chem. Phys. Lett. 1998, 294, 143-152.

[37] D. Andrae, U. Haeussermann, M. Dolg, H. Stoll, H. Preuss, Theor. Chim. Acta 1990, 77, 123141.

[38] K. Eichkorn, F. Weigend, O. Treutler, R. Ahlrichs, Theor. Chem. Acc. 1997, 97, 119-124.

[39] E. D. Glendening, A. E. Reed, J. E. Carpenter, F. Weinhold, NBO, version 3.1. 